\title{
New species of Zodariidae (Arachnida: Aranei) from Vietnam
}

\section{Новые виды пауков семейства Zodariidae (Arachnida: Aranei) из Вьетнама}

\author{
D.V. Logunov \\ A.B. Аогунов
}

The Manchester Museum, The University of Manchester, Oxford Road, Manchester M13 9PL, UK. E-mail: dpavuk@ngs.ru Манчестерский Музей, Университет Манчестера, Оксфорд Роуд, Манчестер M13 9PL, Великобритания.

KEY WORDS: Vietnam, spiders, Aranei, Zodariidae, new species.

КЛЮЧЕВЫЕ СЛОВА: Вьетнам, пауки, Aranei, Zodariidae, новые виды.

ABSTRACT. This paper presents differential diagnoses and descriptions of seven new species of the Zodariidae (Aranei) collected by A.V. Abramov (Zoological Instituted RAS, Saint-Petersburg, Russia) during the 2005-2010 expeditions of the Joint VietnamRussian Tropical Research and Technological Centre: Asceua maculosa sp.n. ( $\sigma^{\top}+$; Vietnam, Lao Cai Province); Mallinella consona sp.n. (+; Vietnam, Bao Ria Vung Tau Province); Mallinella hoangliena sp.n. ( $\sigma^{7}+$; Vietnam, Lao Cai Province); Mallinella ngoclinha sp.n. ( $\sigma^{7}$; Vietnam, Kon Tum Province); Mallinella khanhoa sp.n. ( $\sigma^{7}$; Vietnam, Khanh Hoa Province); Mallinella phansipana sp.n. ( $\sigma^{\top}$; Vietnam, Lao Cai Province); Storenomorpha abramovi sp.n. ( $\sigma^{7}$; Vietnam, Khanh Hoa Province). The current state of knowledge pertaining to SE Asian Zodariidae is briefly discussed.

РЕЗЮМЕ. Статья посвящена дифференциальным диагнозам и описаниям семи новых видов Zodariidae (Aranei), собранными A.В. Абрамовым (Зоологический институт РАН, Санкт-Петербург, Россия) во время экспедиций Совместного Российско-Вьетнамского Тропического научно-исследовательского и технологического центра в период 2005-2010 гг.: Asceua maculosa sp.n. ( $\sigma^{7}$; ; Вьетнам, провинция Лаокай); Mallinella consona sp.n. (†; Вьетнам, провинции Баориа и Вуньтау); Mallinella hoangliena sp.n. ( $\bigcirc^{7}$; В Ветнам, провинция Лаокай); Mallinella ngoclinha sp.n. ( ${ }^{7}$; Вьетнам, провинция Контум); Mallinella khanhoa sp.n. ( $\sigma^{7}$; Вьетнам, провинция Кханьхоа); Mallinella phansipana sp.n. (ऽ'; Вьетнам, провинция Лаокай); Storenomorpha abramovi sp.n. ( $\bigcirc^{\top}$; Вьетнам, провинция Кханьхоа). Кратко обсуждается современное состояние изученности Zodariidae ЮВ Азии.

\section{Introduction}

South-east Asian spiders of the family Zodariidae remain poorly known. Compared to the faunas of Africa and Australia, the zodariid diversity of this region is considered relatively low [Dankittipakul \& Jocqué, 2004]. Of the 77 genera and 935 species of Zodariidae described worldwide [Platnick, 2010], only 113 species (see Table 1) of ten genera and three subfamilies have been recorded from the Oriental Region to date [Jocqué, 1991; Dankittipakul \& Jocqué, 2004, 2006; Ono \& Hashim, 2008; Dankittipakul \& Schwendinger, 2009; Sudhikumar et al., 2009]: viz., Cydrelinae ( $C y$ drela Thorell, 1873), Storenomorphinae (Storenomorpha Simon, 1884) and Zodariinae (Asceua Thorell, 1887; Doosia Kishida, 1940; Euryeidon Dankittipakul et Jocqué, 2004; Heradion Dankittipakul et Jocqué, 2004; Hermippus Simon, 1893; Mallinella Strand, 1907; Melayozodarion Ono et Hashim, 2008; Suffasia Jocqué, 1991). The Vietnamese species assigned to the genus Akyttara Jocqué, 1987 [Ono, 2004b] is probably misplaced, and possibly belongs to a new genus (see below under 'Comments' of the genus Asceua). The record of Zodariellum Andreeva et Tyschchenko, 1968 from Hainan Island, south-east China [Lin \& Li, 2009] requires verification. On the basis of the description and illustrations of the latter authors [Lin \& Li, 2009: fig. $1,5,6]$, the male of their $Z$. serraferum $\mathrm{Lin}$ et $\mathrm{Li}$, 2009 does not possess the tutaculum separated from the cymbium by a deep groove, but it does have a very short embolus and 'conductor', and thus its characters do not correspond to the diagnosis of this genus [cf. Marusik \& Koponen, 2001]. The genus Zodariellum has been reliably recorded only from the Mediterranean and Central Asia.

The zodariid fauna of South Asia, of which 25 species of seven genera have been reported to date [Benjamin \& Jocqué, 2000; Sebastian \& Peter, 2009; etc.] and remain known from original descriptions only, is also worth discussing. The following taxa have been reliably recorded or described: the small genus Suffasia [Benjamin \& Jocqué, 2000], in which three species have been described from India and Sri Lanka and four from Nepal [Jocqué, 1992; Ono, 2006; Sudhikumar et al., 2009]; single species have been described from the genera Storenomorpha [Jocqué \& Bosmans, 1989] and As- 
ceua [Gravely, 1921]; and two species from the genus Hermippus [Jocqué, 1986, 1991]. The Indian records from the genus Lutica Marx, 1891 (4 species; see Sebastian \& Peter [2009]) need to be revised, because this genus is actually restricted to California [Jocqué, 1991]. Three Indian species of Capheris Simon, 1893 [Sebastian \& Peter, 2009] actually belong to the genus Cydrela [Jocqué, 1991; Dankittipakul \& Jocqué, 2006]. Furthermore, all the south Asian records of species from Crypthothele L. Koch, 1872, Storena Walckenaer, 1805 and Zodarion Walckenaer, 1826 also need verification [see Ono \& Hashim, 2008, for a discussion].

To date, 12 species of four genera of Zodariidae have been reported from Vietnam, 10 of which have been described in the last five years [Ono, 2003, 2004ab; Grismado \& Ramírez, 2004; Chami-Kranon \& Ono, 2007]. Of the neighbouring regions, the zodariid fauna of south China has been a subject of recent intensive taxonomic studies, with 27 species of four genera being described from there to date [Song \& Kim, 1997; Song \& Zhu, 1999; Yin \& Yan, 2001; Bao \& Yin, 2002; Yin \& Bao, 2008; Yu et al., 2009; Wang et al., 1999, 2009a,b; Lin \& Li, 2009; Zhang \& Zhu, 2009a,b]. Only one zodariid species has been reported from Laos (Storenomorpha anne Jäger, 2007), but there are numerous undetermined Laotian specimens of the genera Mallinella and Asceua [see Jäger, 2007]. It is clear that the aforementioned number of species does not reflect the true diversity of Zodariidae of the Oriental Region, which can be expected to be at least threefold that known at present. Thus, it is not surprising that a comparatively small general spider collection collected opportunistically in Vietnam by my friend Alexei V. Abramov (Zoological Institute of the RAS, St.Petersburg) during 2005-2010 contains 7 new species of Zodariidae. The aim of the present paper is to describe these new species and to briefly discuss the current state of knowledge of the Zodariidae of SE Asia.

The type material is deposited in the collections of the Zoological Institute RAS (ZISP), St.-Petersburg, Russia (curator V.A. Krivokhatsky) and the Manchester Museum (MMUM), Manchester, UK (curator D.V. Logunov). The format of descriptions follows Ono [2004b], with minor modifications: e.g., no ratios of body measurements are given, only measurements themselves. The following abbreviations are used in the text: AME anterior median eyes, ALE - anterior lateral eyes, AMEAME - distance between AMEs, AME-ALE - distance between AME and ALE, PME - posterior median eyes, PLE - posterior lateral eyes, PME-PME distance between PMEs, PME-PLE - distance between PME and PLE. The sequence of leg segments in measurement data is as follows: femur + patella + tibia + metatarsus + tarsus. All measurements are in $\mathrm{mm}$.

\section{Species account}

The genus Asceua Thorell, 1887

Asceua (s.lat.) is a small and poorly studied genus of Zodariidae, with 19 described species worldwide [Plat- nick, 2010]. Of these, 15 species have been recorded from south and SE Asia [Bosmans \& Hillyard, 1990; Jocqué, 1991; Song \& Kim, 1997; Murphy \& Murphy, 2000; etc.]. Three species have been described from Vietnam [Simon, 1904; Ono, 2004b], with all of them being known only from females. According to Dankittipakul \& Jocqué [2004], species of the genus Asceua differ from other zodariids of SE Asia by their small body size, the absence of a colour pattern on the dorsum, the laterally compressed bulbous, the cymbium having a strongly developed cymbial fold and the very long and meandering insemination ducts. As the type species, $A$. elegans Thorell, 1887 from Myanmar, remains known from a single female [Jocqué, 1991: fig. 63], the best studied and most typical representative of the genus could be considered A. wallacei Bosmans et Hillyard, 1990 from Indonesia, Sulawesi; see Bosmans \& Hillyard [1990: figs 51-55]. The latter species is known from both sexes, is most close to the type species and therefore beyond doubt belongs to the genus Asceua.

The genus Asceua (s.lat.) is a paraphyletic taxon requiring revision. Firstly, four Asceua species described from southern China [Song \& Kim, 1997; Song et al., 1999] constitute a clear species group that differs from A. wallacei in having a well-marked membranous 'conductor' in the male palps [see Song \& Kim, 1997: figs 5, 12, 17; also arrowed in Fig. 3] and in the absence of a central pocket of the epigyne, which occurs both in $A$. elegans and in A. wallacei, as well as in two Vietnamese species [see Ono, 2004b: figs 3, 7]. Furthermore, the Chinese species do not have large and well-marked receptacles, a characteristic feature of true Asceua. Secondly, recently Ono [2009] re-validated the genus Doosia, with the type species D. japonica (Bösenberg et Strand, 1906) from Japan. Earlier, Doosia had been considered a junior synonym of Asceua [see Jocqué, 1991: 40]. According to Ono [2009], besides the type species the genus Doosia also includes $D$. tenera (Thorell, 1895) from Myanmar (ex. Storena t.). Finally, Ono [2004] described Akyttara adorocci Ono, 2004 from southern Vietnam, the species belonging to a small Afrotropical genus Akyttara (in total 4 species). The main reason for the assignment was the presence of a large dorsal scutum in males, yet differences in the conformation of the copulatory organs between $A$. adorocci and typical representatives of Akyttara [see Jocqué, 1987] were not taken into consideration. Later, Ono \& Hashim [2008] concluded that $A$. adorocci may belong to a different, apparently new genus of Zodariidae. However, by its conformation, the male palp of $A$. adorocci [Ono, 2004b: figs 19-24] is very similar to that of the type species of the genus Doosia [Ono, 2009: figs 26-30 on p. 215] and thus this species might also belong to the latter genus.

The congenerity of the Chinese species of Asceua with Doosia is also worth further consideration, but this problem is outside the scope of the present work. However, the new species of Asceua (s.lato) described below is close to its Chinese representatives and displays a clearly marked body coloration (Figs 6,7), which is not 
typical for the genus [see Dankittipakul \& Jocqué, 2004]. Therefore, the assignment of this new species to the genus Asceua (s.lato) is to be considered provisional.

\section{Asceua maculosa sp.n.}

Figs 1-7.

TYPE MATERIAL. The $\sigma^{x}$ holotype and $1 \sigma^{7} 1 \%$ paratypes (ZISP) from North Vietnam, Lao Cai Province, Van Ban Distr., Nam Xay Commune ( $\left.21^{\circ} 58^{\prime} 26^{\prime \prime} \mathrm{N}, 104^{\circ} 02^{\prime} 28^{\prime \prime} \mathrm{E}\right), 900-1200 \mathrm{~m}$ a.s.l., 19.03-15.04.2005, A.V. Abramov (expedition of Russia-Vietnam Tropical Centre).

ETYMOLOGY. From the Latin 'maculosus', meaning motley, variegated. The species has a conspicuous motley lilac-coloured abdomen, differing between males and females (Figs 6, 7).

DIAGNOSIS. The new species is most similar to the south Chinese species A. jianfeng Song et Kim, 1997 (from Hainan) and A. menglun Song et Kim, 1997 (from Yunnan) [see Song \& Kim, 1997: figs 1-5, 9-12]. The male of $A$. maculosa sp.n. differs from those of both Chinese species in having a stronger median apophysis (Figs 2,3) and a wider and stronger membranous 'conductor' (arrowed in Fig. 3). The female of A. maculosa sp.n. differs from all the other females of Asceua described from China by the presence of a pair of dark, well-marked and separated epigynal pockets (Fig. 4), shorter and wider insemination ducts (Fig. 5) and a unique dorsum colour pattern, with a wide light creamcoloured longitudinal band (Fig. 7).

DISTRIBUTION. The type locality only.

DESCRIPTION. Male (the holotype). Measurements. Carapace: 1.65 long, 1.35 wide. Eye sizes and interdistances: AME 0.09, ALE 0.09, PME 0.09, PLE 0.10 (eye ratio: $\mathrm{PLE}>\mathrm{AME}=\mathrm{ALE}=\mathrm{PME}$ ), $\mathrm{AME}-\mathrm{AME}$ touching each other, AME-ALE 0.04, PME-PME 0.11, PME-PLE 0.16. Median ocular area: 0.38 long, 0.17 wide anteriorly, 0.29 wide posteriorly. Clypeus height: 0.43. Cheliceral length: 0.65. Abdomen: 1.55 long, 1.30 wide. Length of leg segments (total leg length): I: $1.40+0.41+1.03+1.18+0.75(4.77) ; \mathrm{II}: 1.19+0.43$ $+0.90+1.05+0.60$ (4.17); III: $1.13+0.43+0.83+$ $1.05+0.53$ (3.97); IV: $1.58+0.45+1.35+1.83+$ 0.80 (6.01). Leg formula: IV, I, II, III. Coloration. Carapace (including the clypeus) uniform brown and shiny, without covering scales. Sternum, maxillae and labium brownish yellow. Chelicerae brown. Abdomen whitish, but dorsum and sides with a reticulate pattern of wide lilac-coloured stripes (Fig. 6), whereas venter with V-shaped lilac-coloured area in front of the spinnerets. Dorsum also with a narrow longitudinal scutum in its anterior half. Book-lung covers and spinnerets orange-yellow. All legs and palps yellow, except for orange-brown femora and patellae. Palp structure as shown in Figs 1-3; the palp possesses a strong median apophysis (Figs 2, 3), a wide and strong membranous 'conductor' (arrowed in Fig. 3) and a well-marked sharp 'tooth' of the distal process directed ventro-laterad; the embolus long and whip-shaped, making a revolution of almost $180^{\circ}$, which is a characteristic feature of Asceua species.
Female (the paratype). Measurements. Carapace: 1.58 long, 1.13 wide. Eye sizes and interdistances: AME 0.09, ALE 0.09, PME 0.09, PLE 0.10 (eye ratio: $\mathrm{PLE}>\mathrm{AME}=\mathrm{ALE}=\mathrm{PME}), \mathrm{AME}-\mathrm{AME}$ touching each other, AME-ALE 0.06, PME-PME 0.10, PME-PLE 0.16 . Median ocular area: 0.39 long, 0.17 wide anteriorly, 0.29 wide posteriorly. Clypeus height: 0.40 Cheliceral length: 0.68. Abdomen: 2.08 long, 1.35 wide. Length of leg segments (total leg length): I: $1.08+0.40$ $+0.93+0.95+0.68$ (4.04); II: $0.85+0.35+0.63+$ $0.68+0.50(3.01)$; III: $0.95+0.43+0.70+0.93+$ 0.58 (3.59); IV: $1.20+0.48+1.05+1.43+0.75$ (4.91). Leg formula: IV, I, III, II. Coloration as in the male, except for the abdomen, which has a wide dorsal cream-coloured longitudinal band and lilac-coloured sides (Fig. 7). Abdomen without scutum. Epigyne and spermathecae as shown in Figs 4, 5; a central epigynal pocket is absent, copulatory openings are hidden in lateral pockets, insemination ducts rather wide, receptacles are not marked and do not differ in their width from the insemination ducts.

\section{The genus Mallinella Strand, 1907}

Mallinella is the most diverse zodariid genus of SE Asia. Almost a half of its described species in the world fauna (47 of 76 valid species of Mallinella; see Platnick [2010]) are known from the Oriental Region [Bosmans \& Hillyard, 1990: sub. Langbiana spp.; Yin \& Yan, 2001; Bao \& Yin, 2002; Tanikawa, 2005; Ono \& Hashim, 2008; Wang et al., 1999, 2009a,b; Dankittipakul \& Schwendinger, 2009; Zhang \& Zhu, 2009a; etc.]. At the same time, only five of the recorded species are known outside their type localities: viz., $M$. cinctipes (Simon, 1893), M. hingstoni (Brignoli, 1982), M. hoosi (Kishida, 1935), M. immaculata Zhang et Zhu, 2009 and $M$. oblonga Zhang et Zhu, 2009 [Ono \& Tanikawa, 1990: sub. Langbiana spp.; Song et al., 1999, 2002; Ono, 2009; Zhang \& Zhu, 2009a]. The genus is in need of revision, for it contains several species groups with clearly different conformation of the copulatory organs. One of these groups of 9 species was recently assigned to a newly erected genus Heradion [see Dankittipakul \& Jocqué, 2004; Chami-Kranon \& Ono, 2007]. It is very likely that $M$. immaculate, recently described from China and Thailand [Zhang \& Zhu, 2009a], should also be transferred to Heradion. To date, there are 7 species of Mallinella described from Vietnam [Hogg, 1922; Ono, 2003, 2004b], yet five of them remain known from a single sex (mainly from males). Descriptions of five new species of Mallinella from various regions of Vietnam are given below.

\section{Mallinella hoangliena sp.n. Figs 8-12.}

TYPE MATERIAL. The $\sigma^{x}$ holotype and $3 \sigma^{7} \sigma^{7} 1+$ paratypes (ZISP) from North Vietnam, Lao Cai Province, c. $6 \mathrm{~km} \mathrm{~W}$ of Sa Pa, $\mathrm{N}$-slope of Phansipan Mt. area, near Tram Ton (station of Hoang Lien Nature Res.), $22^{\circ} 21^{\prime} \mathrm{N}, 103^{\circ} 46^{\prime} \mathrm{E}, 1930-2000 \mathrm{~m}$ a.s.1., 05.2008, A.V. Abramov (expedition of Russia-Vietnam Tropical Centre) 


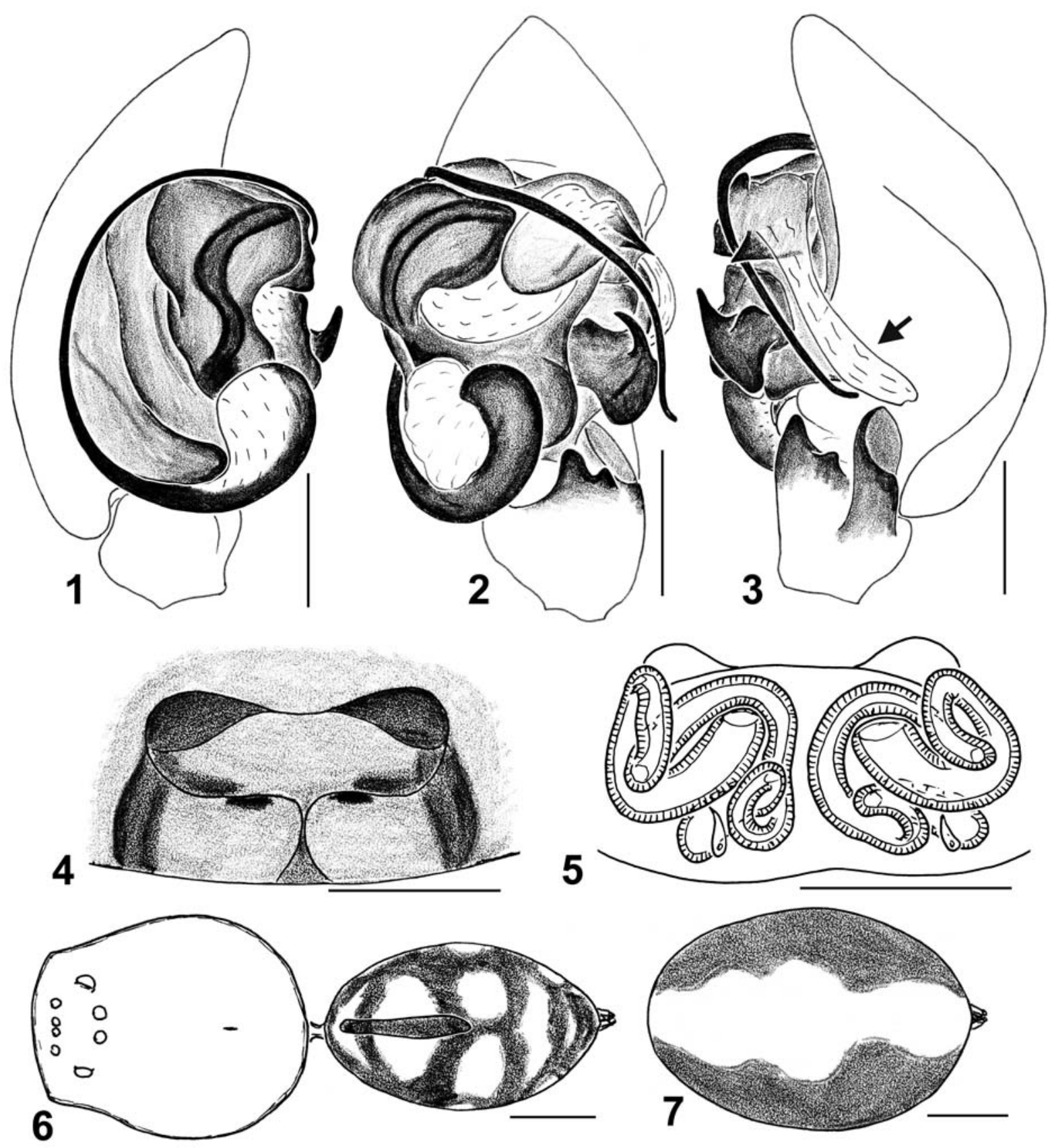

Figs 1-7. Copulatory organs and general appearance of Asceua maculosa sp.n. ( $0^{7}$ - holotype,, — paratype): 1 - male palp, median view; 2 - ditto, ventral view; 3 - ditto, lateral view; 4 - epigyne, ventral view; 5 - spermathecae, dorsal view; 6 - male, general appearance; 7 - female, general appearance. Scale: $0.25 \mathrm{~mm}$.

Рис. 1-7. Копулятивные органы и внешний вид Asceua maculosa sp.n. ( $\sigma^{7}$ - голотип, + — паратип): 1 - пальпа самца, медиально; 2 - тоже, вентрально; 3 - тоже, латерально; 4 - эпигина, вентрально; 5 - сперматеки, дорзально; 6 - внешний вид самца; 7 - внешний вид самки. Масштаб: 0,25 мм.

ETYMOLOGY. From the name of the Hoang Lien Nature Reserve, where the type series was collected.

DIAGNOSIS. By conformation of the copulatory organs, especially of the median apophysis (Fig. 8), the new species is most close to the Japanese species $M$. hoosi (Kishida, 1935) and M. okinawaensis Tanikawa, 2005 [see Ono \& Tanikawa, 1990: figs 3-7, sub.
Langbiana h.; Tanikawa, 2005: fig. 3; Ono, 2009: 214], as well as to the species $M$. martensi (Ono, 1983) from central Nepal [see. Ono, 1983: fig. 1-4, sub. Storena $m$.]; although the latter author [Ono, 2003] transferred M. martensi to Mallinella, this combination was not included by [Platnick, 2010] in his online Catalog. The male of M. hoangliena sp.n. reliably differs from those 


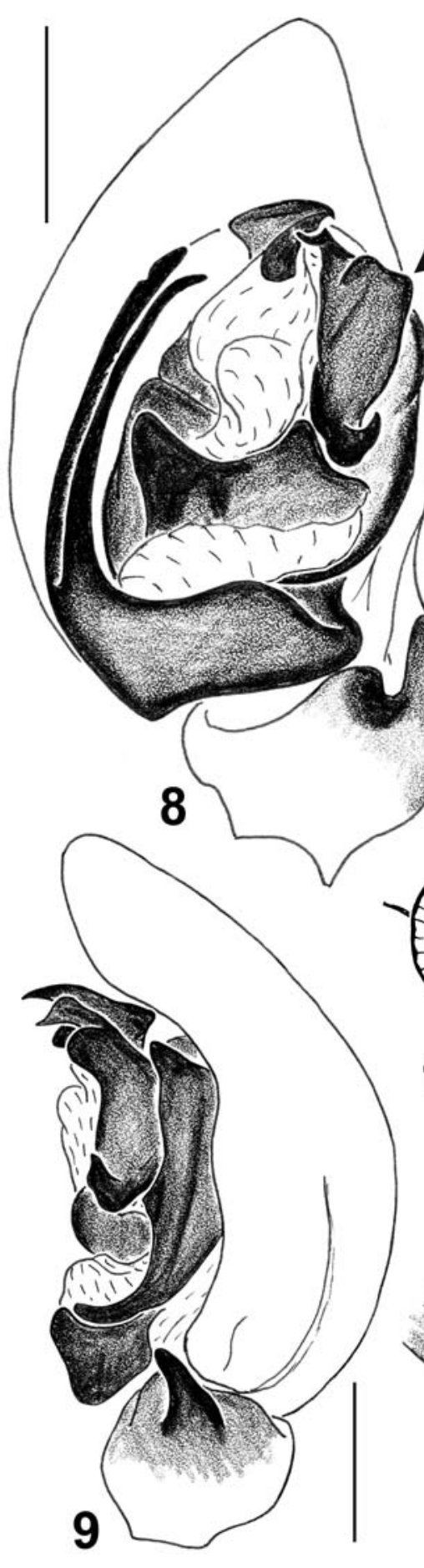

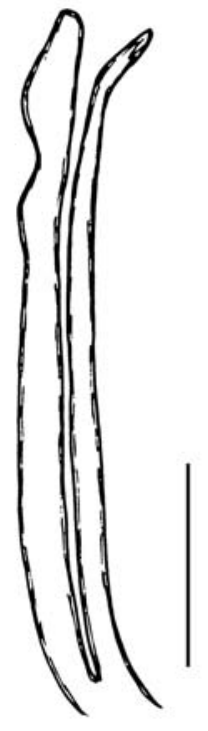

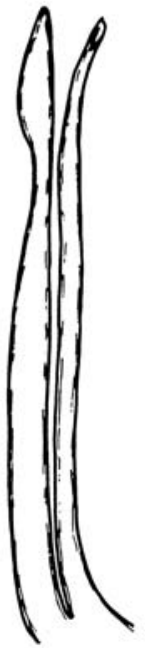

10

15

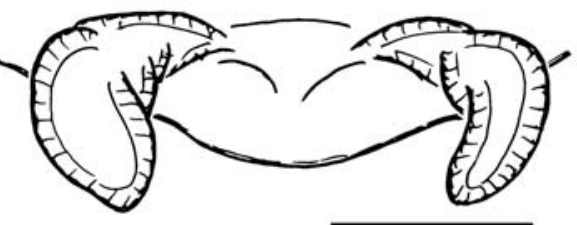

12

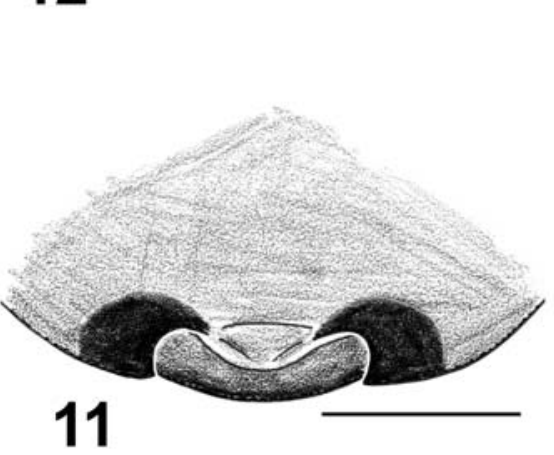

14

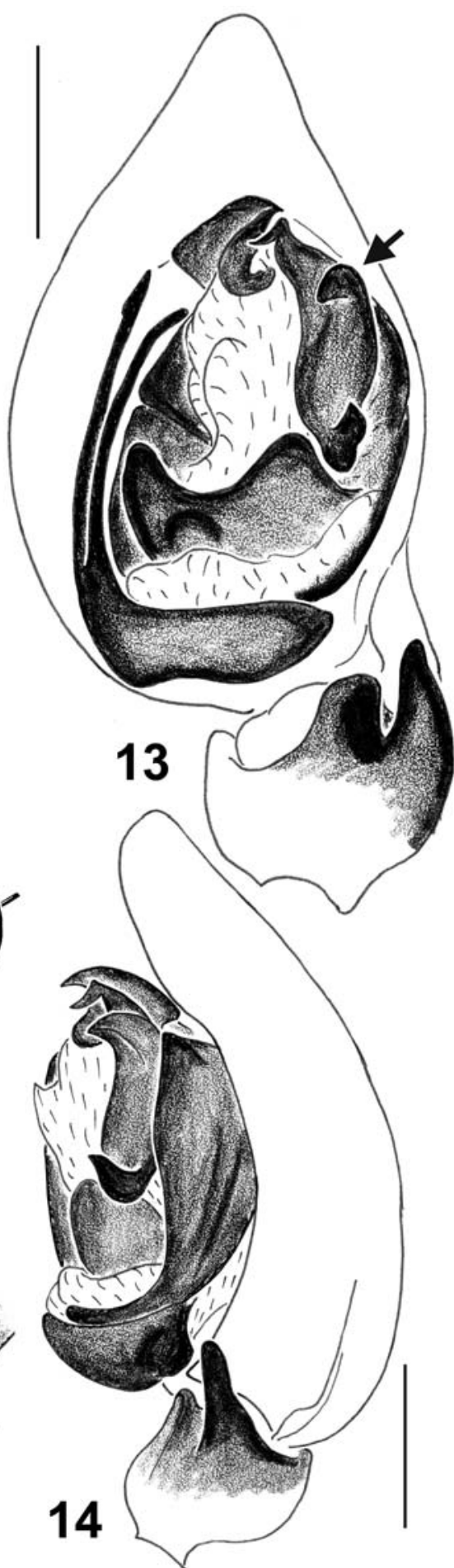

Figs 8-15. Copulatory organs of Mallinella hoangliena sp.n. (8-12) ( $\sigma^{7}$ — holotype, $q$ - paratype) and Mallinella ngoclinha sp.n. (13-15) (holotype): 8,13 - male palp, ventral view; $9,14-$ ditto, lateral view; 10,15 - embolar division; $11-$ epigyne, ventral view; 12 - spermathecae, dorsal view. Scale: $(8-9,11-14) 0.5 \mathrm{~mm},(10,15) 0.25 \mathrm{~mm}$.

Рис. 8-15. Копулятивные органы Mallinella hoangliena sp.n. (8-12) (б — голотип, о — паратип) и Mallinella ngoclinha sp.n. (13-15) (голотип): 8, 13 - пальпа самца, вентрально; 9, 14 - тоже, латерально; 10,15 - эмболярный отдел; 11 - эпигина, вентрально; 12 - сперматеки, дорзально. Масштаб: (8-9, 11-14) 0,5 мм, (10, 15) 0,25 мм. 
of all the related species in the structure of its embolar division: viz., in having a thin and equally-developed embolus and 'conductor' [sensu Jocqué, 1991] (Fig. $10)$, as well as in the proportions of the median apophysis, which has a thinner proximal hook and a much stronger and wider proximal end (arrowed in Fig. 8). By the conformation of the epigyne and spermathecae (Figs 11, 12), the female of M. hoangliena sp.n. is most similar to that of M. hoosi [Ono \& Tanikawa, 1990: figs 8 , 9, sub. Langbiana $h$.], but can be distinguished from it by the dorsum coloration: in the new species the dorsum is lilac-coloured, with three transverse white stripes in its rear half (as in the majority of Mallinella species), whereas in both sexes of $M$. hoosi the dorsum is chestnut-coloured, with a wide whitish longitudinal stripe [see Ono \& Tanikawa, 1990: fig. 2]. See also comments under the 'Diagnosis' of M. phansipana sp.n.

DISTRIBUTION. The type locality only.

DESCRIPTION. Male (the holotype). Measurements. Carapace: 4.30 long, 3.05 wide. Eye sizes and interdistances: AME 0.30, ALE 0.21, PME 0.23, PLE 0.23 (eye ratio: $\mathrm{AME}>\mathrm{PME}=\mathrm{PLE}>\mathrm{ALE}$ ), $\mathrm{AME}-\mathrm{AME}$ 0.11, AME-ALE 0.20, PME-PME 0.16, PME-PLE 0.41. Median ocular area: 0.70 long, 0.63 wide anteriorly, 0.59 wide posteriorly. Clypeus height: 0.90 . Cheliceral length: 1.38. Abdomen: 4.25 long, 3.00 wide. Length of leg segments (total leg length): I: $2.70+1.05+2.05$ $+2.55+2.00$ (10.35); II: $2.85+1.05+2.55+2.40+$ 1.70 (10.55); III: $2.60+1.15+1.90+2.55+1.45$ (9.65); IV: $3.20+1.20+2.05+3.70+1.90$ (12.05). Leg formula: IV, II, I, III. Coloration. Carapace (including clypeus) uniformly black with a bluish tint, shiny, without covering scales. Sternum bright orange. Maxillae and labium yellow-orange. Chelicerae redbrown, but bright yellow medially, near the fang. Abdomen with a lilac-coloured dorsum and sides, and with light yellow venter. Dorsum in its rear half with three transverse whitish lines, and anteriorly with a narrow brown scutum. Book-lung covers and spinnerets yellow-orange. All legs: coxae, femora and tibiae light brown; the remaining segments light orange. The palps light brown, their structure as in Figs 8-10; the palps with a wide median apophysis, having a rather thin proximal hook (Figs 8, 9), the embolus visibly narrower than the 'conductor' [sensu Jocqué, 1991] but of almost the same length (Fig. 10), the ventral tibial process shorter than the prolateral one.

Female (the paratype). Measurements. Carapace: 5.0.5 long, 3.55 wide. Eye sizes and interdistances: AME 0.28, ALE 0.26, PME 0.18, PLE 0.25 (eye ratio: AME $>$ ALE $>$ PLE $>$ PME), AME-AME 0.13, AME-ALE 0.30, PME-PME 0.25, PME-PLE 0.50. Median ocular area: 0.83 long, 0.65 wide anteriorly, 0.70 wide posteriorly. Clypeus height: 1.25 . Cheliceral length: 2.15 . Abdomen: 4.85 long, 3.60 wide. Length of leg segments (total leg length): I: $3.00+1.25+2.40+2.30+$ 1.80 (10.75); II: $2.75+1.30+2.10+2.25+1.50$ (9.90); III: $2.80+1.40+1.95+2.50+1.30(9.95)$; IV: $3.50+1.45+2.70+3.60+1.80$ (13.05). Leg formula: IV, I, III, II. Coloration as in the male, but there is no scutum and carapace with a red spot in front of the AMEs. The epigyne and spermathecae as in Figs 11, 12; the epigyne is very narrow and procurved (Fig. 11), the insemination ducts short and rather thick, receptacles bent backward (Fig. 12).

\section{Mallinella ngoclinha sp.n.}

Figs 13-15.

TYPE MATERIAL. The $\sigma^{\top}$ holotype and $\sigma^{\top}$ paratype (ZISP) from Vietnam, Kon Tum Province, Central Highlands, $2-3 \mathrm{~km} \mathrm{~W}$ of Ngoc Linh Mt., $15^{\circ} 05^{\prime} \mathrm{N}, 107^{\circ} 57^{\prime} \mathrm{E}, 1700-2000 \mathrm{~m}$ a.s.1., 20.III08.IV.2006, A.V. Abramov (expedition of Russia-Vietnam Tropical Centre)

ETYMOLOGY. From the name of Ngoc Linh Mt., where the type series was collected.

DIAGNOSIS. By conformation of the copulatory organs, especially of the relatively narrow median apophysis (arrowed in Fig. 13), the new species is most close to $M$. nomurai Ono, 2003, described from north Vietnam (Vihn Phu Province: Tam Dao; see Ono [2003: figs 2-5]), but can be easily distinguished from it by the much narrower branches of the embolar division (Fig. 15) and by the shape of the distal tegular process.

DISTRIBUTION. The type locality only.

DESCRIPTION. Male (the holotype). Measurements. Carapace: 3.75 long, 2.85 wide. Eye sizes and interdistances: AME 0.21, ALE 0.21, PME 0.17, PLE 0.20 (eye ratio: $A L E=A M E>$ PLE $>$ PME), AME-AME 0.10, AME-ALE 0.20, PME-PME 0.16, PME-PLE 0.37. Median ocular area: 0.51 long, 0.50 wide anteriorly, 0.51 wide posteriorly. Clypeus height: 0.75 . Cheliceral length: 1.50. Abdomen: 3.75 long, 2.55 wide. Length of leg segments (total leg length): I: $2.60+1.00+2.20$ $+2.20+1.60$ (9.60); II: $2.40+1.00+1.90+2.05+$ 1.40 (8.75); III: $2.30+1.00+1.65+2.10+1.25$ (8.30); IV: $2.75+1.05+2.20+3.05+1.50(10.55)$. Leg formula: IV, I, II, III. Coloration. Carapace (including clypeus) uniformly dark brown and shiny, without covering scales; there is a small red spot in front of AMEs. Sternum, maxillae and labium orange-yellow. Chelicerae yellowish brown. Abdomen: dorsum and sides lilac-coloured; venter yellow, with longitudinal lilac-coloured lines. Dorsum with three transverse whitish lines in its rear half, and anteriorly with a narrow brown scutum. Book-lung covers and spinnerets yellow-orange. All legs and palps orange-yellow, without colour pattern. The palp structure as in Figs 13-15; the palp has a relatively narrow median apophysis, with strong proximal and distal hooks (Figs 13, 14); as in the majority of Mallinella species, the embolus and 'conductor' [sensu Jocqué, 1991] are of equal thickness and almost of the same length (Fig. 15); ventral and prolateral processes are of the same length.

Female is unknown.

\section{Mallinella khanhoa sp.n. \\ Figs 16-19.}

TYPE MATERIAL. The $\sigma^{7}$ holotype (ZISP) from Vietnam, Khanh Hoa Province, Hon Ba Mt., c. $30 \mathrm{~km} \mathrm{~W}$ of Nha Trang, 

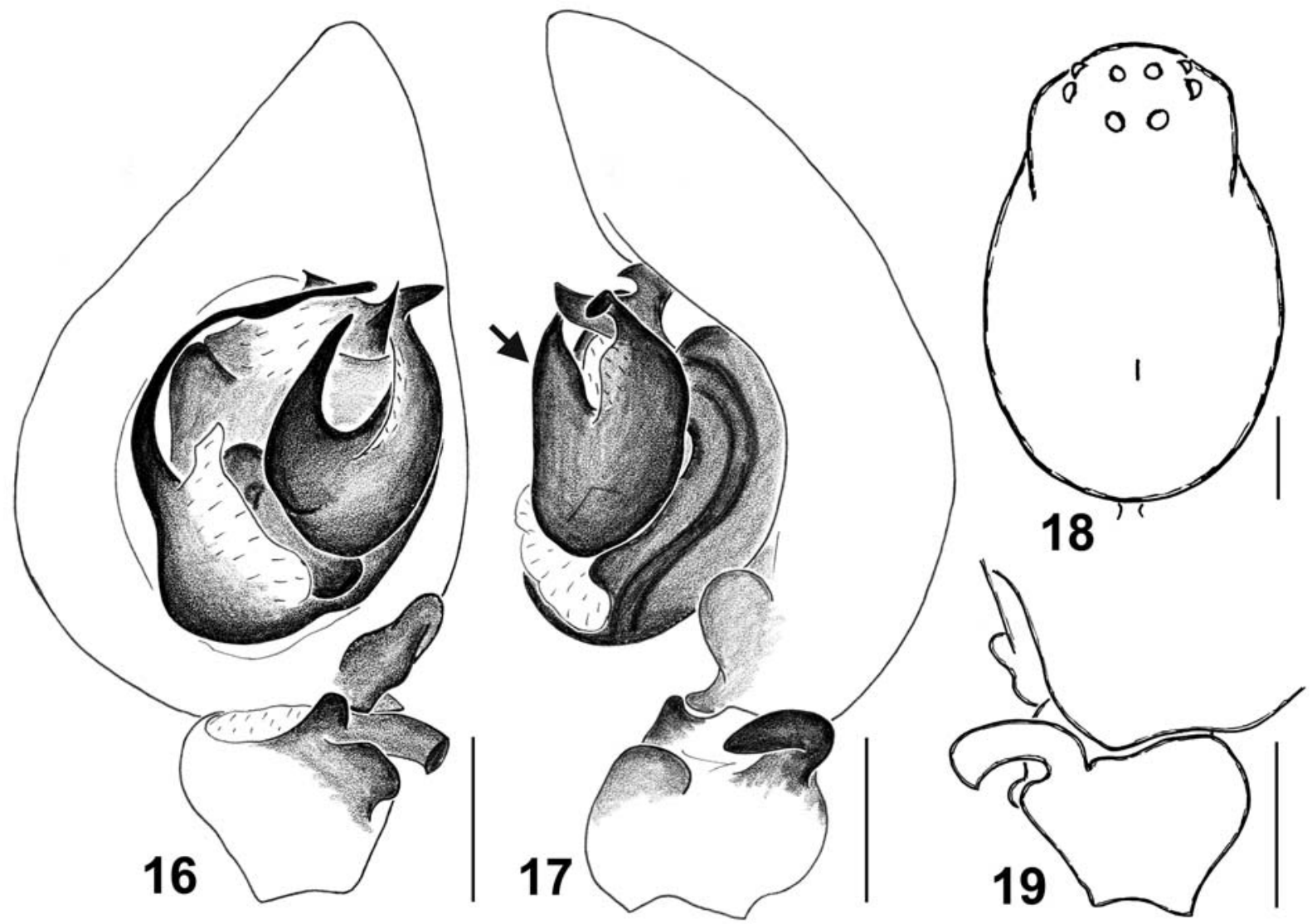

Figs 16-19. Copulatory organs and general appearance of Mallinella khanhoa sp.n. (holotype): 16 - male palp, ventral view; $17-$ ditto, lateral view; 18 - male carapace, dorsal view; 19 - tibial apophysis, dorsal view. Scale: $(16,17,19) 0.25 \mathrm{~mm}$, (18) $0.5 \mathrm{~mm}$.

Рис. 16-19. Копулятивные органы и внешний вид Mallinella khanhoa sp.n. (голотип): 16 - пальпа самца, вентрально; $17-$ тоже, латерально; 18 - головогрудь самца, дорзально; 19 - голенный отросток пальпы, дорзально. Масштаб: $(16,17,19)$ 0,25 мм, (18) 0,5 мм.

$12^{\circ} 07^{\prime} \mathrm{N}, 108^{\circ} 57^{\prime}$ E, c. 1500 m a.s.1., 15-23.IV.2008, A.V. Abramov (expedition of Russia-Vietnam Tropical Centre).

ETYMOLOGY. From the name of Khanh Hoa Province, where the holotype was collected.

DIAGNOSIS. The new species has an unusually strong, V-shaped median apophysis (arrowed in Fig. 17). The only other species that possesses a median apophysis of a comparable size (but not thickness!) is M. korubei Ono, 2003 described from central Vietnam (Tua Thien $\mathrm{Hu}$ : Bach Ma National Park) from a single male [Ono, 2003: figs 15, 16]. The male of $M$. khanhoa sp.n. can easily be separated from the latter species by the uni-ramous branches of the median apophysis (Fig. 17 ; bi-ramous in $M$. korubei), and by the strongly bent dorso-lateral process of the palpal tibia (Fig. 19; straight in $M$. korubei). Besides, $M$. korubei has a bi-ramous embolar division [Ono, 2003: fig. 18], as in the majority of Mallinella species [see Wang et al., 2009a: figs 10, 21; Ono, 2009: figs 2-2-35; etc.], whereas that of M. khanhoa sp.n. is uni-ramous (Fig. 16), with no 'conductor' [sensu Jocqué, 1991].

DISTRIBUTION. The type locality only.

DESCRIPTION. Male (the holotype). Measurements. Carapace: 3.00 long, 2.15 wide. Eye sizes and interdistances: AME 0.15, ALE 0.14, PME 0.14, PLE 0.14 (eye ratio: $\mathrm{AME}>\mathrm{ALE}=\mathrm{PLE}=\mathrm{PME}$ ), AME-AME 0.05, AME-ALE 0.19, PME-PME 0.11, PME-PLE 0.24. Median ocular area: 0.44 long, 0.37 wide anteriorly, 0.43 wide posteriorly. Clypeus height: 0.50 . Cheliceral length: 1.08. Abdomen: 2.50 long, 1.90 wide. Length of leg segments (total leg length): I: $1.95+0.78+1.63$ $+1.65+1.30(7.31)$; II: $1.83+0.83+1.33+1.48+$ 1.18 (6.65); III: $1.75+0.78+1.28+1.68+1.10$ (6.59); IV: $2.15+0.83+1.90+2.68+1.53$ (9.09). Leg formula: IV, I, II, III. Coloration. Carapace (including clypeus) uniformly brown and shiny, without covering scales (Fig. 18). Sternum, maxillae and labium orange-yellow. Chelicerae brown. Abdomen: dorsum dark lilac-coloured, anteriorly with a narrow brown scutum; sides and venter yellow-grey. Book-lung covers and spinnerets yellow-orange. All legs and palps orange-yellow, without colour pattern. The palpal structure as in Figs 16, 17, 19; the palp possesses a strong $\mathrm{V}$-shaped median apophysis (arrowed in Fig. 17) and a spine-shaped distal apophysis; the embolus singular, which is atypical for the genus Mallinella; the dorsolateral apophysis is strongly bent (Fig. 19). 


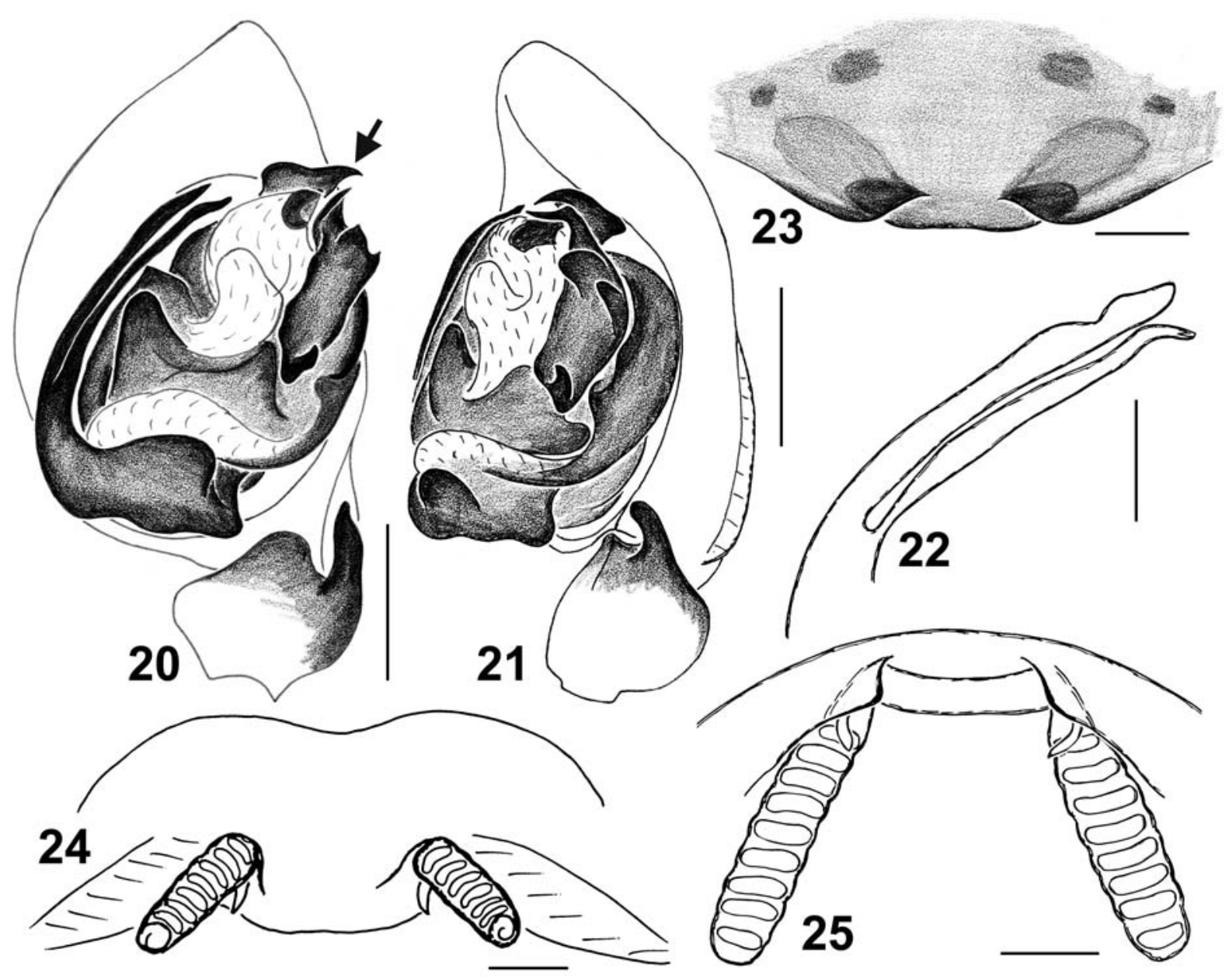

Figs 20-25. Copulatory organs of Mallinella phansipana sp.n. (20-22) (holotype) and Mallinella consona sp.n. (23-25) (holotype): 20 - male palp, ventral view; 21 - ditto, lateral view; 22 - embolar division; 23 - epigyne, ventral view; 24 - spermathecae, dorsal view; 25 - ditto, rear view. Scale: $(20,21) 0.5 \mathrm{~mm},(22-25) 0.25 \mathrm{~mm}$.

Рис. 20-25. Копулятивные органы Mallinella phansipana sp.n. (20-22) (голотип) и Mallinella consona sp.n. (23-25) (голотип): 20 - пальпа самца, вентрально; 21 - тоже, латерально; 22 - эмболярный отдел; 23 - эпигина, вентрально; 24 - сперматеки, дорзально; 25 - тоже, сзади. Масштаб: $(20,21)$ 0,5 мм, (22-25) 0,25 мм.

Female is unknown.

\section{Mallinella phansipana sp.n.}

Figs 20-22.

TYPE MATERIAL. The $O^{T}$ holotype and $O^{T}$ paratype (ZISP) from North Vietnam, Lao Cai Province, c. $6 \mathrm{~km}$ W of Sa Pa, north slope of Phansipan Mt. region, near Tram Ton Station of Hoang Lien National Park $\left(22^{\circ} 21^{\prime} \mathrm{N}, 103^{\circ} 46^{\prime} \mathrm{E}\right), 1930-2000 \mathrm{~m}$ a.s.1. 05.2010, A.V. Abramov (exp. of Russia-Vietnam Tropical Centre). PARATYPES: $4 \mathrm{O}^{7} \mathrm{O}^{7}$ (MMUM), same province, c. $2.5 \mathrm{~km} \mathrm{SW}$ of $\mathrm{Sa} \mathrm{Pa}$, near Cat Cat Village $\left(22^{\circ} 19^{\prime} 37^{\prime \prime} \mathrm{N}, 103^{\circ} 49^{\prime} 21^{\prime \prime E}\right), 1400$ $1450 \mathrm{~m}$ a.s.1., 05.2010, A.V. Abramov (exp. of Russia-Vietnam Tropical Centre).

ETYMOLOGY. From the Phansipan Mt., where the holotype was collected.

DIAGNOSIS. By the structure of the wide and sharpened distal tegular apophysis (arrowed in Fig. 20 ), the new species is most similar to M. hoangliena sp.n. collected from the same locality and known from both sexes (see above). Both species can be distin- guished by the shape of the median apophysis and of the tegulum (cf. Figs 20-21 and 8-9).

DISTRIBUTION. The type locality only.

DESCRIPTION. Male (the holotype). Measurements. Carapace: 4.30 long, 3.05 wide. Eye sizes and interdistances: AME 0.30, ALE 0.24, PME 0.20, PLE 0.25 (eye ratio: $A M E>A L E>$ PME $>$ PLE), AME-AME 0.10, AME-ALE 0.20, PME-PME 0.18, PME-PLE 0.43. Median ocular area: 0.69 long, 0.65 wide anteriorly, 0.63 wide posteriorly. Clypeus height: 0.96 . Cheliceral length: 1.20. Abdomen: 4.15 long, 2.95 wide. Length of leg segments (total leg length): I: $3.00+1.10+2.55$ $+2.40+1.90(10.95)$; II: $2.60+1.20+1.95+2.40+$ 1.65 (9.80); III: $2.65+1.10+1.85+2.55+1.40$ (9.55); IV: $3.40+1.20+2.60+3.75+1.80$ (12.75). Leg formula: IV, I, III, II. Coloration. Carapace (including clypeus) uniformly dark brown and shiny, without covering scales. Sternum orange-red. Maxillae and labium yellowish brown. Chelicerae dark brown. Ab- 


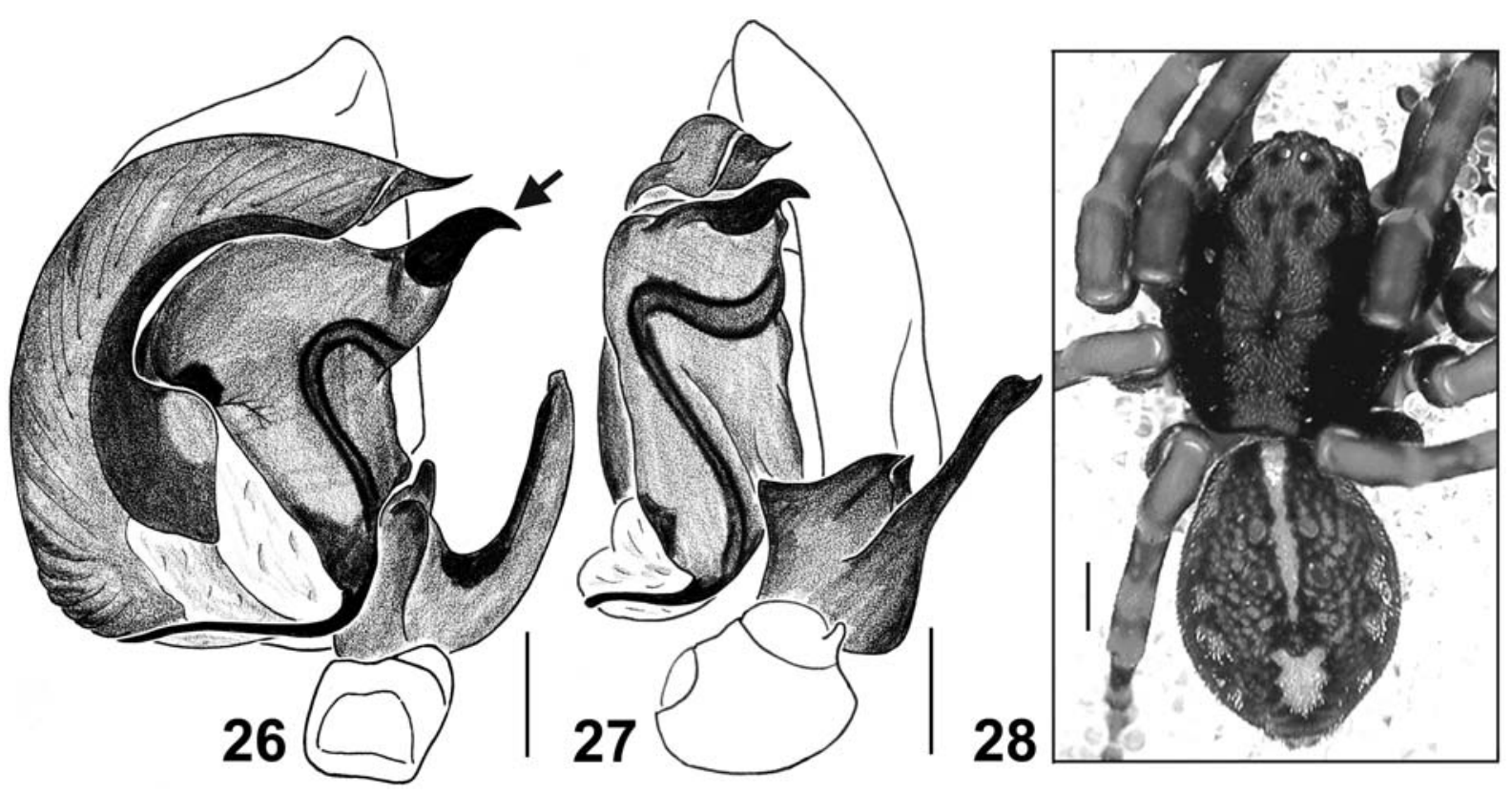

Figs 26-28. Copulatory organs and general appearance of Storenomorpha abramovi sp.n. (holotype): 26 - male palp, ventral view; 27 - ditto, lateral view; 28 - male general appearance, dorsal view. Scale: $(20,21) 0.5 \mathrm{~mm}$, (22) $1 \mathrm{~mm}$.

Рис. 26-28. Копулятивные органы и внешний вид Storenomorpha abramovi sp.n. (голотип): 26 - пальпа самца, вентрально; 27 - тоже, латерально; 28 - внешний вид самца, дорзально. Масштаб: $(20,21)$ 0,5 мм, (22) 1 мм.

domen: dorsum and sides grey, venter yellowish grey. Dorsum with a narrow brownish scutum in its anterior half, and with three transverse white lines and a distal white spot in its posterior half. Book-lung covers orange and chitinized. Spinnerets orange-yellow; a small ventral scutum in front of the spinnerets. All legs: coxae yellow, femora dark brown, remaining segments orange-yellow. Palps brown, their structure as in Figs 20-22; the palp has a wide and sharpened distal tegular process (arrowed in Fig. 20) and an equally-developed embolus and 'conductor' [sensu Jocqué, 1991], yet the embolus is visibly narrower (Fig. 22).

Female is unknown.

\section{Mallinella consona sp.n.}

Figs 23-25.

TYPE MATERIAL. The $q$ holotype and $q$ paratype (ZISP) from South Vietnam, Bao Ria - Vung Tau Province, central part of Con Son Island $\left(8^{\circ} 42^{\prime} \mathrm{N}, 106^{\circ} 35^{\prime} \mathrm{E}\right), 5-300 \mathrm{~m}$ a.s.1., 06.2010, A.V. Abramov (exp. of Russia-Vietnam Tropical Centre).

ETYMOLOGY. From the island of Con Son, where the type series was collected.

DIAGNOSIS. Of the Mallinella species known from both sexes or females the new species is most close to M. hamata (Bosmans \& Hillyard, 1990) from Sulawesi. Both species possess unusually long receptacles (Fig. 25; cf. figs 21-23 in Bosmans \& Hillyard [1990]), but can easily be separated by the narrower epigynal plate in M. consona sp.n. (Fig. 23) and the different position of the receptacles.

DISTRIBUTION. The type locality only.

DESCRIPTION. Male is unknown.
Female (the holotype). Measurements. Carapace: 4.25 long, 3.00 wide. Eye sizes and interdistances: AME 0.29, ALE 0.21, PME 0.23, PLE 0.25 (eye ratio: AME $>$ PLE $>$ PME $>$ ALE), AME-AME 0.15, AME-ALE 0.10, PME-PME 0.24, PME-PLE 0.33. Median ocular area: 0.65 long, 0.71 wide anteriorly, 0.63 wide posteriorly. Clypeus height: 0.96. Cheliceral length: 1.20. Abdomen: 4.15 long, 2.95 wide. Length of leg segments (total leg length), but legs II and IV don't have distal segments: I: $3.40+1.10+3.05+3.40+2.40$ (13.25); II: $3.10+1.15+2.30+$ no other segments; III: $3.00+1.10+2.45+3.20+1.90$ (11.65); IV: $3.80+$ $1.20+3.45+4.70+$ no tarsus. Leg formula: IV, I, III, II. Coloration. Carapace red-brown, shiny, but the cephalic region and clypeus are visibly darker (dark brown), the thoracic region is lighter, with red margins. Sternum orange-yellow. Maxillae and labium brownish yellow. Chelicerae dark brown. Abdomen grey, with yellow-grey venter. Dorsum with three transverse white lines and a distal spot in its distal half. Book-lungs and spinnerets yellow. All legs orange-yellow. Palps yellowish brown. Epigyne and spermathecae as in Figs 23-25; the spermathecae have unusually long receptacles (Fig. 25).

\section{The genus Storenomorpha Simon, 1884}

Storenomorpha is an unusual genus of the Zodariidae, numbering 16 valid species [Platnick, 2010] and being restricted to SE Asia, from NE India and S China to Thailand and Vietnam [Murphy \& Murphy, 2000; Yin \& Bao, 2008; Yu et al., 2009; Zhang \& Zhu, 2009b]. 
Table 1. Species numbers of ten genera of the Zodariidae of SE Asia in four zoogeographic regions*. Таблица 1. Количество видов десяти родов Zodariidae ЮB Азии в четырех зоогеографических областях*.

\begin{tabular}{|c|c|c|c|c|}
\hline \multirow[t]{2}{*}{ Genera/Роды } & \multicolumn{4}{|c|}{ Zoogeographic Regions } \\
\hline & Afrotropical & Madagascar & Oriental & Australian \\
\hline Аsсеиа & 2 & 1 & 15 & 1 \\
\hline Cydrela & 13 & & 6 & \\
\hline Doosia & & & 2 & \\
\hline Euryeidon & & & 6 & \\
\hline Heradion & & & 9 & \\
\hline Hermippus & 7 & & 2 & \\
\hline Mallinella & 29 & & 49 & 1 \\
\hline Melayozodarion & & & 1 & \\
\hline Storenomorpha & & & 16 & \\
\hline Suffasia & & & 7 & \\
\hline In Total/Всего & 41 & 1 & 113 & 2 \\
\hline
\end{tabular}

* - Only the genera that have been reliably recorded from SE Asia (see Introduction) are included in the Table. As these genera do not contain species from the Palaearctic, Nearctic and Neotropical Regions, these regions were excluded from the table.

* - В таблицу включены только роды, которые достоверно отмеченны из ЮВ Азии (см. Введение). В обсуждаемых родах нет видов из Палеарктической, Неарктической и Неотропической областей, поэтому данные области не включены в таблицу.

The genus was revised by Jocqué \& Bosmans [1989] and it is the type genus of the nominative subfamily Storenomorphinae [sensu Jocqué, 1991]. The majority of species are known from their type localities only, except for a couple of Chinese species [see Yin \& Bao, 2008]. Two species (S. comottoi Simon, 1884 from Myanmar and S. reinholdae Jocqué \& Bosmans, 1989 from Thailand) remain known from males only [Jocqué \& Bosmans, 1989]. To date, a single Storenomorpha species has been described from Vietnam, namely, $S$. paguma Grismado et Ramírez, 2004. The male and female of this species were provisionally matched and are likely to belong to different species [see Grismado \& Ramírez, 2004]. A new Storenomorpha species is described below from Khanh Hoa Province of Vietnam.

\section{Storenomorpha abramovi sp.n.}

Figs 26-28.

TYPE MATERIAL. The $\sigma^{7}$ holotype (ZISP) from Vietnam, Khanh Hoa Province, Hon Ba Mt., c. $30 \mathrm{~km} \mathrm{~W}$ of Nha Trang, $12^{\circ} 07^{\prime} \mathrm{N}, 108^{\circ} 57^{\prime} \mathrm{E}, \mathrm{c} .1500 \mathrm{~m}$ a.s.l., $15-23 . I V .2008$, A.V. Abramov (expedition of Russia-Vietnam Tropical Centre).

ETYMOLOGY. This species is dedicated to my friend and colleague, Dr Alexei V. Abramov (ZISP, St.-Petersburg, Russia), who has been collecting spiders from different regions of Vietnam for my research for a number of years.

DIAGNOSIS. The new species differs from all the known Storenomorpha species in having a long and straight dorso-lateral tibial process (Fig. 27) and a sickle-shaped tegular apophysis (arrowed in Fig. 26). Of the described species, only S. yunnan Yin et Bao, 2008 from south China has got a relatively long dorsolateral tibial process [see Yin \& Bao, 2008: figs 9-11], but the latter is of a spiral shape.

DISTRIBUTION. The type locality only.

DESCRIPTION. Male (the holotype). Measurements. Carapace: 4.70 long, 3.90 wide. Eye sizes and interdistances: AME 0.16, ALE 0.24, PME 0.17, PLE
0.21 (eye ratio: ALE $>$ PLE $>$ PME $>$ AME), AME-AME 0.10 , AME-ALE 0.14, PME-PME 0.16, PME-PLE 0.59. Median ocular area: 0.54 long, 0.49 wide anteriorly, 0.51 wide posteriorly. Clypeus height: 0.55 . Cheliceral length: 1.38. Abdomen: 4.85 long, 3.60 wide. Length of leg segments (total leg length): I: $3.50+1.90+2.75+$ $2.30+1.35$ (11.80); II: $3.25+1.85+2.30+2.05+$ 1.20 (10.65); III: $2.85+1.55+1.70+1.55+0.90$ (8.55); IV: $3.40+1.60+2.55+2.10+1.05(10.70)$. Leg formula: I, IV, II, III. Coloration. Carapace black, its surface is finely rugose; in the middle there is a short and wide dark red longitudinal stripe sparcely covered with white elongated scales (Fig. 22). Clypeus dark brown, almost black. Sternum, maxillae and labium dark orange. Chelicerae dark brown, medially with yellow spot near the fang. Abdomen yellow, with dense reticulate colour pattern. Dorsum with a pair of large, well-marked sigillae, a yellow band on the cardiac spot and an elongated yellow spot in its distal third (Fig. 28). All legs with dark brown (almost black) femora; the remaining segments reddish yellowish, with brown patches and rings along their length. The palpal structure as in Figs 26, 27; the palpal tibia with a very long, narrow and straight process, a wide and square ventrolateral process, a sickle-shaped tegular apophysis (arrowed in Fig. 26) and a strong 'conductor' sharpened at its end, which is typical for Storenomorpha males.

Female is unknown.

\section{Discussion}

Although the current state of knowledge of the Zodariidae of SE Asia is rather poor and a serious analysis of this fauna is not yet possible, it is worth providing comparative data on a number of described and valid species from various zoogeographic regions (see Table 1).

As evident from the table, all the genera recorded from the Oriental Region are limited in their distribu- 
tion to the Old World and also have no Palaearctic species in their composition. Three genera (Euryeidon, Heradion and Melayozodarion) have been described and one genus (Doosia) was re-validated in the last three years. All of them are restricted to SE Asia [Dankittipakul \& Jocqué, 2004; Ono, 2007, 2009; Ono \& Hashim, 2008]. Of 935 valid species of Zodariidae [Platnick, 2010], 113 species (12\%; Table 1) are restricted to the Oriental Region. Of these, 45 species (40\%) were described from there in the last five years; 10 species have been described from Vietnam [Ono, 2003, 2004ab; Grismado \& Ramírez, 2004; ChamiKranon \& Ono, 2007]. On the one hand, this fact is evidence that Vietnam, as well as Laos [see Jäger, 2007], constitute centers of the present species diversity of Zodariidae, at least in such genera as Asceua, Heradion and Mallinella. On the other hand, this fact is also indicative of a generally poor knowledge of the spiders, including the Zodariidae, of SE Asia.

ACKNOWLEDGEMENTS. I wish to thank my friend and colleague, Dr Alexei V. Abramov (ZISP, St.-Petersburg, Russia) for making his Vietnamese spider collections available for this study. Dr David Penney (Manchester, UK) is thanked for his kind linguistic help.

\section{References}

Bao Y.H., Yin C.M. 2002. A new species of the genus Mallinella and a female supplement of $M$. maolanensis from China (Araneae: Zodariidae) // Acta zootax. sin. Vol.27. P.85-88.

Benjamin S.P., Jocqué R. 2000. Two new species of the genus Suffasia from Sri Lanka (Araneae: Zodariidae) // Rev. suisse Zool. T.107. P.97-106.

Bosmans R., Hillyard P. 1990. Spiders of the family Zodariidae from Sulawesi, Indonesia (Arachnida: Araneae: Zodariidae) // Bull. Brit. arachnol. Soc. Vol.8. P.147-160.

Chami-Kranon T., Ono H. 2007. On Vietnamese representatives of the ant spider genus Heradion (Araneae: Zodariidae) // Zootaxa. Vol.1395. P.59-68.

Dankittipakul P., Jocqué R. 2004. Two new genera of Zodariidae (Araneae) from Southeast Asia // Rev. suisse Zool. T.111. P.749-784.

Dankittipakul P., Jocqué R. 2006. Two new species of Cydrela Thorell (Araneae: Zodariidae) from Thailand // Raffles Bull. Zool. Vol.54. No.1. P.93-101.

Dankittipakul P., Schwendinger, P.J. 2009. Mallinella thaleri, a new spider species from southern Thailand (Araneae: Zodariidae) // C. Kropf \& P. Horak (eds.). Towards a natural history of arthropods and other organisms. In memoriam Konrad Thaler. Contributions to Natural History. Vol.12. P.381-389.

Gravely F.H. 1921. The spiders and scorpions of Barkuda Island // Rec. Indian Mus. Calcutta. Vol.22. P.399-421.

Grismado C.J., Ramírez M.J. 2004. A new species of the genus Storenomorpha Simon from Vietnam (Araneae, Zodariidae) // Zootaxa. Vol.453. P.1-7.

Hogg H.R. 1922. Some spiders from south Annam // Proc. zool. Soc. London. P.285-312.

Jäger P. 2007. Spiders from Laos with descriptions of new species (Arachnida: Araneae) // Acta arachnol. Vol.56. P.29-58.

Jocqué R. 1986. A revision of the genus Hermippus Simon, 1893 (Araneae: Zodariidae) // J. nat. Hist. Vol.20. P.7-22.

Jocqué R. 1987. Descriptions of new genera and species of African Zodariinae with a revision of the genus Heradida (Araneae, Zodariidae) // Revue zool. afric. T.101. P.143-163.
Jocqué R. 1991. A generic revision of the spider family Zodariidae (Araneae) // Bull. Am. Mus. nat. Hist. Vol.201. P.1-160.

Jocqué R. 1992. A new species and the first males of Suffasia with a redelimitation [sic!] of the subfamilies of the Zodariidae (Araneae) // Rev. suisse Zool. T.99. P.3-9.

Jocqué R., Bosmans R. 1989. A revision of the genus Storenomorpha Simon (Araneae, Zodariidae) // Spixiana. Vol.12. P.125134.

Lin Yu.C., Li S.Q. 2009. Zodariellum serraferum sp. nov., a new spider species (Araneae, Zodariidae) from Hainan Island, China // Acta zootax. sin. Vol.34. No.1. P.10-13.

Marusik Yu.M., Koponen S. 2001. Spiders of the family Zodariidae from Mongolia (Arachnida: Araneae) // Reichenbachia. Bd.34. P.39-48.

Murphy F., Murphy J. 2000. An introduction to the spiders of south east Asia with notes on all the genera. Kuala Lumpur: Malaysian Nature Society. 624 pp.

Ono H. 1983. Zodariidae aus dem Nepal-Himalaya. I. Neue Arten der Gattung Storena Walckenaer 1805 (Arachnida: Araneae) // Senckenbergiana biol. Bd.63. S.211-217.

Ono H. 2003. Four new species of the family Zodariidae (Arachnida, Araneae) from Vietnam. Bull. Nat. Sci. Mus., Tokyo (A). Vol.29. P.131-139.

Ono H. 2004a. Three new species of the genus Mallinella (Araneae, Zodariidae) from Vietnam // Bull. Nat. Sci. Mus., Tokyo (A). Vol.30. P.1-7.

Ono H. 2004b. Spiders of the family Zodariidae (Araneae) from Dambri, Lam Dong Province, southern Vietnam // Bull. Nat. Sci. Mus., Tokyo (A). Vol.30. P.67-75.

Ono H. 2006. Two new species of spiders of the family Zodariidae (Araneae) from eastern Nepal // Zootaxa. No.1325. P.319326.

Ono H. (ed.) 2009. The spiders of Japan: with keys to the families and genera and illustrations of the species. Kanagawa: Tokai Univ. Press. 738 pp.

Ono H., Hashim R. 2008. Four new species of the family Zodariidae (Araneae) from Malaysia // Mem. Nat. Sci. Mus., Tokyo. Vol.45. P.41-51.

Ono H., Tanikawa A. 1990. A revision of the Japanese spiders of the genus Langbiana (Araneae, Zodariidae) // Mem. Nat. Sci. Mus., Tokyo. Vol.23. P.101-112.

Platnick N. 2010. The World Spider Catalog, Version 10.0, (Zodariidae pages last updated June 11th 2010), American Museum of Natural History. Online at: <http://research.amnh.org/ entomology/spiders/catalog/INTRO1.html>

Sebastian P.A., Peter K.V. (eds.). 2009. Spiders of India. Himayatnagar: Univ. Press (India) Private Ltd. 614 pp.

Simon E. 1904. Descriptions de quelques arachnides nouveaux faisant partie de la collection du Musee d'histoire naturelle de Geneve // Rev. suisse Zool. T.12. P.65-70.

Song D.X., Kim J.P. 1997. On seven new species of the family Zodariidae (Araneae) from China // Korean Arachnol. Vol.13. No.1. P.7-17.

Song D.X., Zhang J.X., Li D. 2002. A checklist of spiders from Singapore (Arachnida: Araneae) // Raffles Bull. Zool. Vol.50. P.359-388.

Song D.X., Zhu M.S., Chen J. 1999. The Spiders of China. Shijiazhuang: Hebei Sci. Technol. Publ. House. 640 pp.

Sudhikumar A.V., Jocqué R., Sebastian P.A. 2009. A new species of the ant spider genus Suffasia (Araneae: Zodariidae) from the Western Ghats, India, with a key to the species of the genus // Zootaxa. Vol.2203. P.59-64.

Tanikawa A. 2005. A new species of the spider genus Mallinella and the first description of the male of M. sadamotoi (Araneae: Zodariidae) // Acta arachnol. Vol.54. P.99-101.

Wang X.P., Ran J.C., Chen H.M. 1999. A new species of Mallinella from China (Araneae, Zodariidae) // Bull. Brit. arachnol. Soc. Vol.11. P.193-194.

Wang Q.B., Yin C.M., Griswold C., Peng X.J. 2009a. Three new species of the genus Mallinela [sic] (Zodariidae: Araneae) from Yunnan Province, China // Zootaxa. Vol.2005. P.47-56. 
Wang Q.B., Yin C.M., Peng X.J. 2009b. Description of Mallinella cymbiforma sp. nov. from Hunan Province, China (Zodariidae, Araneae) // Acta arachnol. Sin. Vol.34. P.14-17.

Yin C.M., Bao Y.H. 2008. Two new species of the spider genus Storenomorpha from China (Araneae: Zodariidae) // Acta arachnol. Sin. Vol.17. P.65-71.

Yu H., Jin Z.Y., Liu F.X., Chen J. 2009. Two new species of the genus Storenomorpha from China (Araneae, Zodariidae) // Acta arachnol. Sin. Vol.18. No.1. P.11-17.

Yin C.M., Yan H.M. 2001. A new species of the genus Mallinella from Hunan, China (Araneae: Zodariidae) // Acta arachnol. Sin. Vol.10. P.5-7.
Zhang B.S., Zhu M.S. 2009a. Three new species of the ant spider genus Mallinella Strand, 1906 (Araneae: Zodariidae) from China // Zootaxa. Vol.2212. P.62-68.

Zhang B.S., Zhu M.S. 2009b. Two new species of the genus Storenomorpha from China (Araneae: Zodariidae) // Acta Arachnol. Vol.58. No.2. P.91-95.

Responsible editor K. Mikhailov 